\title{
Dissent, Dissatisfaction and Papal Self-Fashioning: Pope Gregory IX's Response to the Thirteenth-Century Reform Movement in the Facade Mosaic of San Pietro in Vaticano
}

\author{
Catherine D. Harding
}

Volume 22, numéro 1-2, 1995

URI : https://id.erudit.org/iderudit/1072512ar

DOI : https://doi.org/10.7202/1072512ar

\section{Aller au sommaire du numéro}

\section{Éditeur(s)}

UAAC-AAUC (University Art Association of Canada | Association d'art des universités du Canada)

\section{ISSN}

0315-9906 (imprimé)

1918-4778 (numérique)

Découvrir la revue

Citer cet article

Harding, C. D. (1995). Dissent, Dissatisfaction and Papal Self-Fashioning: Pope Gregory IX's Response to the Thirteenth-Century Reform Movement in the Facade Mosaic of San Pietro in Vaticano. RACAR : Revue d'art canadienne / Canadian Art Review, 22(1-2), 29-39. https://doi.org/10.7202/1072512ar
Résumé de l'article

Dans cet article, nous nous proposons de démontrer que les changements apportés par le pape Grégoire IX à la mosaïque de la basilique vaticane, datant principalement du début de la chrétienté, devraient être attribués en partie à la façon dont le pape envisageait le renouvellement spirituel de l'Église du bas moyen-âge. En décidant d'inclure une forme modifiée de la Déisis parmi les Vingt-quatre viellards de l'Apocalypse, le pape effectuait un remaniement important du message d'origine qui affirmait l'autorité du pontife romain. Ce changement reflétait aussi la préoccupation de l'époque en ce qui concerne l'intercession de la Vierge et des saints au jour du jugement dernier. En même temps, Grégoire insérait son portrait près du groupe de la Déisis. Son geste, imbu d'une piété humble et effacée, donne une impression de désir ardent et de dévotion en présence de Dieu; de ce fait, le portrait de Grégoire représente une étape importante dans la formation de l'image d'un pape par lui-même au Xllle siècle. D’un côté, les aspects les plus publics des changements apportés à cette mosaïque par le pape Grégoire, suggèrent que les modifications étaient destinées à répondre aux crises spirituelles auxquelles l'Église dut faire face pendant son pontificat. D'un point du vue plus personnel, il est possible que le sens de cette mosaïque soit associé au désir du pape d'assurer son propre salut en achetant son entrée au Paradis.
Tous droits réservés (C) UAAC-AAUC (University Art Association of Canada | Association d'art des universités du Canada), 1997
Ce document est protégé par la loi sur le droit d'auteur. L'utilisation des services d'Érudit (y compris la reproduction) est assujettie à sa politique d'utilisation que vous pouvez consulter en ligne.

https://apropos.erudit.org/fr/usagers/politique-dutilisation/ 


\title{
Dissent, Dissatisfaction and Papal Self-Fashioning: Pope Gregory IX's Response to the Thirteenth-Century Reform Movement in the Facade Mosaic of San Pietro in Vaticano
}

\author{
Catherine D. Harding, University of Victoria
}

\section{Résumé}

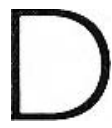

ans cet article, nous nous proposons de démontrer que les changements apportés par le pape Grégoire IX à la mosaïque de la basilique vaticane, datant principalement du début de la chrétienté, devraient être attribués en partie à la façon dont le pape envisageait le renouvellement spirituel de l'Église du bas moyenàge. En décidant d'inclure une forme modifiée de la Déisis parmi les Vingt-quatre viellards de l'Apocalypse, le pape effectuait un remaniement important du message d'origine qui affırmait l'autorité du pontife romain. Ce changement reflétait aussi la préoccupation de l'époque en ce qui concerne l'intercession de la Vierge et des saints au jour du jugement dernier. En même temps, Grégoire insérait son portrait près du groupe de la Déisis. Son geste, imbu d'une piété humble et effacée. donne une impression de désir ardent et de dévotion en présence de Dieu; de ce fait, le portrait de Grégoire représente une étape importante dans la formation de l'image d'un pape par lui-même au Xllle siècle. D'un côté, les aspects les plus publics des changements apportés à cette mosaique par le pape Grégoire, suggèrent que les modifications étaient destinées à répondre aux crises spirituelles auxquelles l'Église dut faire face pendant son pontificat. D'un point du vue plus personnel, il est possible que le sens de cette mosaique soit associé au désir du pape d'assurer son propre salut en achetant son entrée au Paradis.
T he twelfth and thirteenth centuries in medieval Europe are marked as a time of spiritual ferment, of dissent and dissatisfaction with many aspects of institutional religious life as it had heretofore been practiced. ${ }^{1}$ Indeed, some historians of medieval spirituality consider this to be a time of change as fundamental, deep and profound as the sixteenth-century Reformation. Although the aim of the Roman Church was to maintain its purpose and function, it also tried to adjust its beliefs and institutions to meet the demands being made upon it. Two popes in particular, Innocent III (1198-1216) and his nephew Gregory IX (1227-1241), were instrumental in attempting to restructure and renew the many faces of the Church, with the view that salvation would be achieved within the matrix of one universal Church. ${ }^{2}$ Both men were ardent defenders of their special position between the people and God. Both sought to recuperate the sites of the Holy Land through the promotion of crusading, and both wished to accommodate key aspects of the reform movement, with its emphasis on mission, both at home and abroad. Innocent and Gregory also strove to consolidate the links between the Roman Church and the apostolic poverty movement, a movement which found potent witnesses in the austere and devout lives of saints such as Dominic, Francis, and his close companion, Clare. ${ }^{3}$ For instance, we know that Innocent gave up wearing rich vestments in 1207 , adopting instead a simple tunic of undyed white wool; this type of identification with the ideals of the vita apostolica, or a return to the way of life of Christ and the apostles, permeated all levels of the Church at this time. ${ }^{4}$

Since the early history of the papacy, an integral part of the pontiff's identity had been his ability to convey an impression of magnificentia. ${ }^{5}$ However, in the general cli- mate of dissatisfaction and reform of the thirteenth century, Innocent and Gregory had to be careful not to give offence, while also maintaining important papal prerogatives and traditions, such as the investment in the material fabric of the city's ecclesiastical institutions. Both individuals demonstrated a restrained approach to the social acts of patronage normally required of magnificent princes of the Church. ${ }^{6}$ Instead, they preferred to provide social services for Rome's citizens, such as poorhouses, hospitals and hostels, and to maintain comfortable, safe palaces for their families. ${ }^{7}$ Their reluctance to make grand visual statements during this period of personal and corporate reform and renewal must be allied to their sense of spiritual identity, to the notion that art must serve a larger purpose than papal aggrandizement or self-glorification and commemoration. Accordingly, when they did decide to spend on building projects, or other smaller-scale works of art, they chose to focus on monuments that would have a high profile within the city of Rome and be well placed to convey new themes that were in line with the ideals of the reform movement. ${ }^{8}$ When Innocent III decided to "restore" the Vatican apse mosaic, he did so with a clear sense of how this work would be an effective medium to convey the message of reform. ${ }^{9}$ As we shall see below, Innocent's hope of salvation for all under the aegis of a universal Church, with the pope placed in a special relationship between God and the people, was expressed in the titulus of the mosaic and its representation of the papal portrait. The mosaic also served to promote devotion to the Eucharist and the miracle of Transubstantiation, a doctrinal tenet that played a crucial role in the ritual life of the Church, yet was also a source of much confusion and religious dissent during the twelfth and thirteenth centuries. For example, in 1209 In- 
Figure 1. Apse mosaic of San Pietro in Vaticano by Domenico Tasselli, Rome, Archivio di San Pietro, A. 64 Ter, fol. 50 (Photo: Vatican).

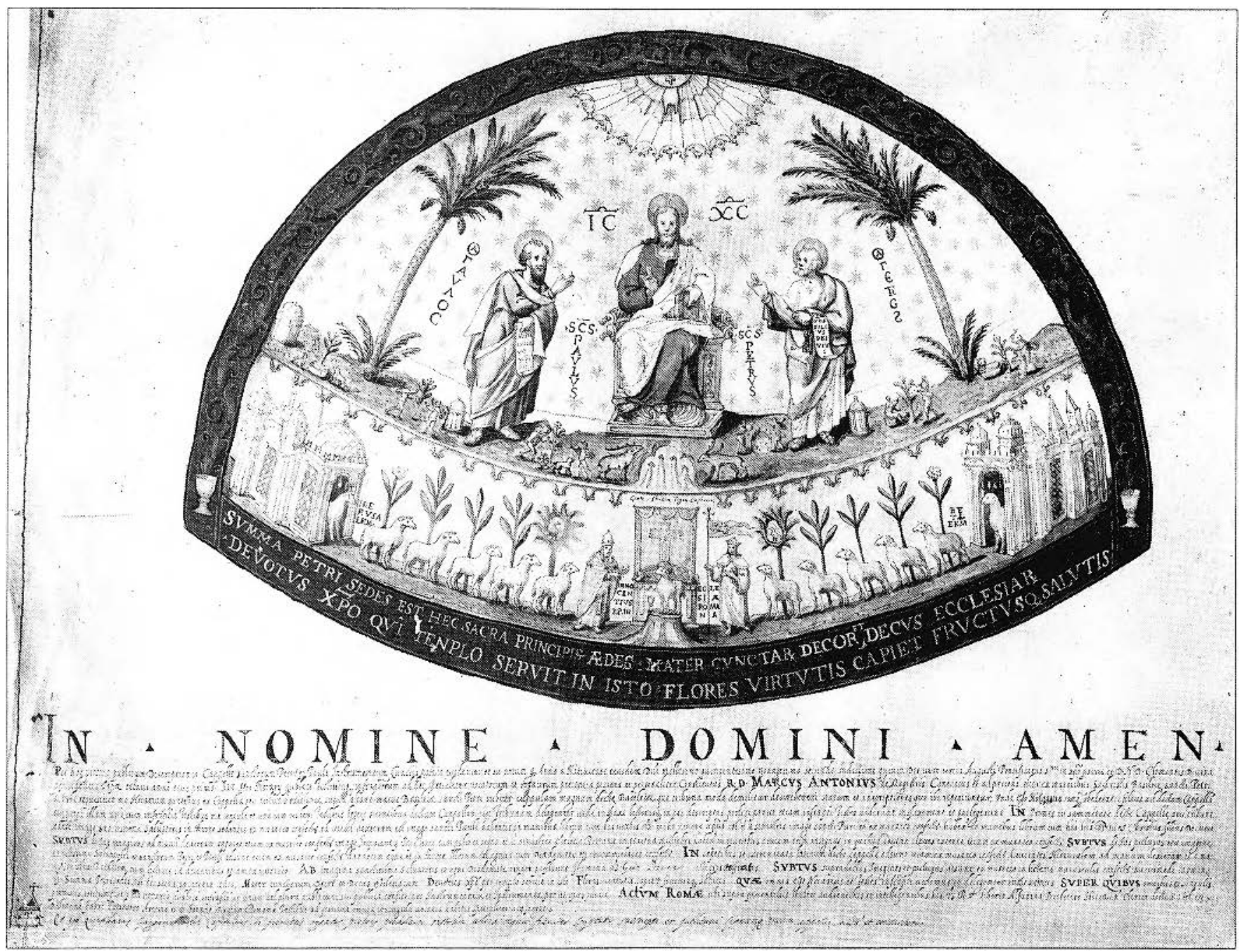

nocent condemned the views of Amalric of Bène as heretical, when Amalric, claiming that God was in all things always, said that the words of the consecration of the Host did not transubstantiate the bread and wine, but rather merely brought forth the presence of God which had already been present therein. ${ }^{10}$

Several decades later, Gregory IX brought the same sense of a renewed spirituality to his commissioning of the Vatican facade mosaic. Although not previously discussed in the literature, the mosaic commission reflects Gregory's sensitivity to his role as spiritual leader of Christendom at a difficult moment in its history. The dominant reading of the program in the past has focussed exclusively on Gregory's concern to defend the political rights of the Roman Church in the light of his notion of the plenitudo potestatis. ${ }^{1}$ However, a fuller understanding of the mosaic asks that we also assess its relationship to the Roman Church's response to the medieval reform movement.
Another important dimension of the mosaic's meaning depends on whether we view the work through the lens of public or private theories of reception. It will be suggested below that Gregory may have felt a need to include his portrait in the iconographic programme of the facade mosaic in part because he too hoped to secure the intercession of Christ and the Virgin Mary on the Day of Judgement. Our interpretation of Gregory's image in the light of public/private moments of reception, papal politics, or as a medium to communicate themes of religious renewal, reminds us of the extraordinary multivalency of public art, a perspective that is being increasingly acknowledged in art historical literature. ${ }^{12}$

As the commissions for the Vatican apse and facade mosaics were clearly intended to complement each other, it is worth re-examining what is known about Innocent's commission, before considering the evidence for the Petrine exterior. The Vatican apse mosaic is now lost, with only a 
few fragments of the mosaic, including the head of Innocent III, surviving the final demolition of the basilica in 1606. ${ }^{13}$ In the early Christian work, Christ would have been standing between Peter and Paul, following the formula of a traditio legis, or transference of the Law to the Apostles. Innocent decided to retain many features of the original mosaic, the palm trees, Nilotic landscape and frieze of lambs, proceeding from Bethlehem and Jerusalem respectively, with the main difference being that Christ was shown enthroned between SS Peter and Paul, as seen in the antiquarian drawing accompanying Giacomo Grimaldi's description of the basilica (fig. 1). ${ }^{14}$ In the main field of the apse mosaic, then, Innocent III apparently wished to remain true to a theme that would invoke a sense of the past, a moment in the glorious history of the early papacy. ${ }^{15}$

However, the figures of Innocent III, Ecclesia Romana and at least one aspect of the agnus dei image in the lower register were not part of the earlier scheme. Innocent's decision to pair his self-portrait with the personification of the Roman Church represents an important modification of the earlier scheme. These figures indicate his concern to reiterate traditional notions of papal authority, although the means he used to convey this message departed from what had gone before. No longer the pious donor figure of earlier artistic traditions, he apparently wished to transcend the particularity of his own personality to be represented as the pope, in a universalizing gesture that marks a radical new departure in papal self-fashioning. ${ }^{16}$ The titulus of the mosaic further asserts the importance of the apostolic succession and papal supremacy: "THIS IS THE SEE OF SAINT PETER, THIS THE TEMPLE OF THE PRINCE [OF THE APOSTLES], THE GLORY AND MOTHER OF ALL CHURCHES..."17

Yet this was not all he intended: he demonstrated a clear sense of art's purpose to convey an important new didactic message in the detail of the agnus dei. It has been convincingly argued that the detail of the Lamb with its blood flowing into a chalice was not present in the early Christian original. ${ }^{18}$ Instead, it would have simply shown the Paschal lamb on Mount Zion, in line with the earlier medieval tradition of the agnus dei. ${ }^{19}$ The blood flowing into the chalice was, in Innocent's mind, directly associated with Christ's sacrifice and His remission of the sins of the faithful, an event that was commemorated on the altar below in the ritual life of the Church. Thus were the faithful provided with a bold declaration of the symbolic purpose of the Eucharist, a theme that had been dear to his heart as early as ca. 1195, when he wrote De mysteris missae. ${ }^{20}$ This detail of the image is therefore a striking visual complement to the decrees promulgated at the Fourth Lateran
Council of 1215, by which Innocent sought to increase devotion to the Eucharist by further defining its theology and providing clear instructions for its presentation within the ritual life of the Church. ${ }^{21}$ As Bolton suggests in her work on Innocent III, the impact of the remodelled mosaic on the audience of 1,200 archbishops, metropolitans, bishops and abbots attending the Fourth Lateran Council must have been overwhelming. ${ }^{22}$

Later in the century Gregory IX decided once again to focus on the embellishment of Saint Peter's. ${ }^{23}$ As such, his facade mosaic made a fitting companion to Innocent's work. Innocent is known to have restored the Vatican facade mosaic, but it seems that the more extensive job of remodelling fell to his nephew. ${ }^{24}$ However, the contemporary source of the Vita Gregorii Noni merely states that: "Then, indeed at the basilica of the Prince of the Apostles above the vestibule of the main door, he clad with gilded stone a wall which had been erected to a very great height, and he enhanced it with the beauty of noble images." 25 Two details of the Gregorian iconographic program warrant further investigation in this article, for they contribute to a more nuanced set of readings of the lost mosaic. They are, firstly, the introduction of Deesis imagery as a key modification to the original decorative scheme. The second important change is in the way in which Gregory decided to have himself represented in the mosaic.

Although known to scholars, the various sources that may be used to reconstruct the original appearance of the facade mosaic before its destruction in the early seventeenth century are recounted here in support of new reading(s) of its message. ${ }^{26}$ If we turn first to the evidence for the early Christian original, we know that the Vatican facade was covered with a narrative mosaic composition at the time of Pope Leo the Great (440-461). He also contributed funding for an extensive pictorial cycle on the nave walls and apse of the church, as well as financing a number of important structural repairs to the Constantinian fabric. ${ }^{27} \mathrm{We}$ learn from an eighth-century pilgrim that the names of two individuals, Marinianus and his wife Anastasia, were included in the dedicatory inscription of the facade mosaic; Leo had apparently convinced them to contribute to the costs of the commission, in fulfilment of a vow made to the Apostle Peter. ${ }^{28}$

The original appearance of this mosaic may be represented in the eleventh-century manuscript of the vita of Pope Gregory I, produced at the monastery of Farfa near Rome (Eton College ms. 124, fol. 122) (fig. 2). The upper east front of the basilica terminated in a gabled roof and featured a single row of three arched windows. The manuscript image shows the agnus dei (without chalice) enclosed 
in a medallion, placed just below the gable; this detail may accurately reflect an important modification to the early Christian original made at the time of Pope Sergius I in response to the requirements of canon 82 of the Quinisext Council of $692 .{ }^{29}$ Directly underneath the agnus dei are the symbols of the Four Evangelists, who seem to be carrying rotuli or books; the 24 Elders of the Apocalypse are grouped around the windows. This theme, with its apocalyptic overtones, was clearly a significant choice for the exterior of the Petrine basilica. ${ }^{30}$ Such themes of judgement later became commonplace in the facade decoration of churches throughout medieval Europe. ${ }^{31}$

The thirteenth-century composition is recorded in several seventeenth-century drawings from the hand of Domenico Tasselli, which were intended to complement Grimaldi's description of the mosaic (figs. 3, 4). ${ }^{32}$ The drawings indicate that the upper part of the west facade wall below the gable was fitted out with a cavetto moulding, and the original round-headed windows were replaced with a double row of tripartite tracery windows, three to each level. ${ }^{33}$ Presumably it was felt that the overhanging moulding would protect the surface of the mosaic from the elements, as well as displaying it to better advantage. ${ }^{34}$

Grimaldi's text is worth quoting in extenso, for it is apparently a reliable and detailed description of the lost facade mosaic (Addendum, Document 1 for Latin text); an additional paragraph of his text is discussed separately below. He writes:

The exterior facade of the old basilica of San Pietro, which was adorned with mosaic by the great Pope Gregory IX, had these images: Our Saviour Jesus Christ in the throne of his majesty, blessing with his thumb and the ring conjoined; on his right, the Blessed Virgin Mary, on his left St Peter. At the feet of the Saviour the image of Gregory IX kneeling in his papal habit with chasuble and cloak, who, almost prostrate, offers a golden coin over a cushion at the feet of the Saviour. The four evangelists in the guise of a lion, an angel, an eagle and an ox holding the books of the evangelists. Beneath these figures have been portrayed standing images representing these same evangelists as men, that is on the right side of the Saviour. St Matthew with a book in which are the words: "Jesus took up Peter, James and John." Next to Matthew, St Mark holding a book in which is the beginning of his gospel. On the other side, to the Saviour's left, St John

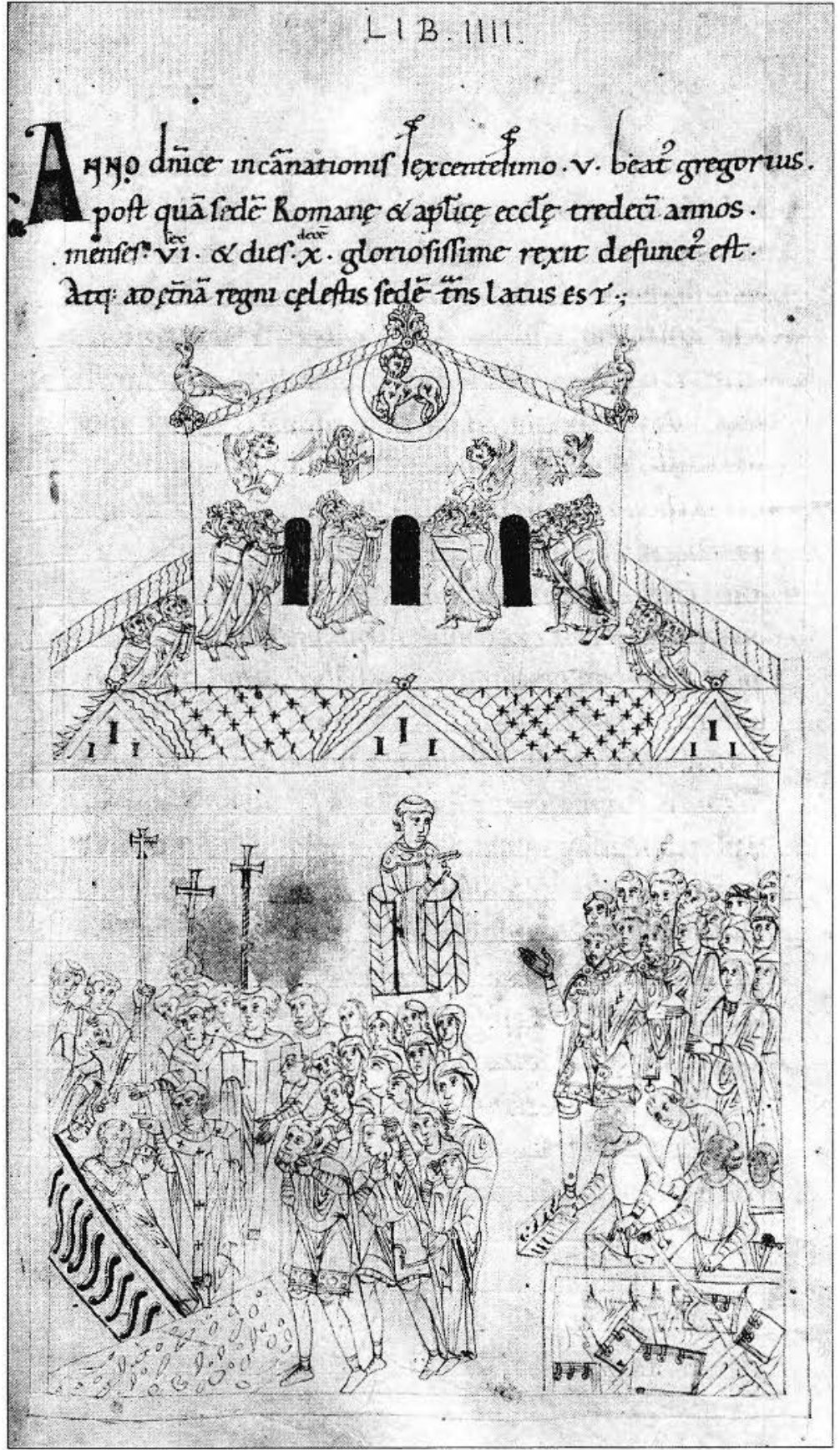

in old age with a book reciting the beginning of his gospel. Next to him, St Luke with the book of his gospel. Beneath these images are seen the 24 Elders offering crowns to the Saviour, one of whom was renewed by Eugenius IV, as his heraldic insignia shows. In the border dividing the upper images of the evangelists from the lower ones of the Elders, these lines are read in mosaic: AS THE BURNING SUN SHINES ABOVE EVERY STAR, AND JUST AS GOLD GLEAMS ABOVE OTHER METALS, AND DOCTRINE IS 
Figure 3. Exterior of San Pietro in Vaticano by Domenico Tasselli. Rome, Archivio di San Pietro, A. 64 Ter, fol. 10 (Photo: Vatican).

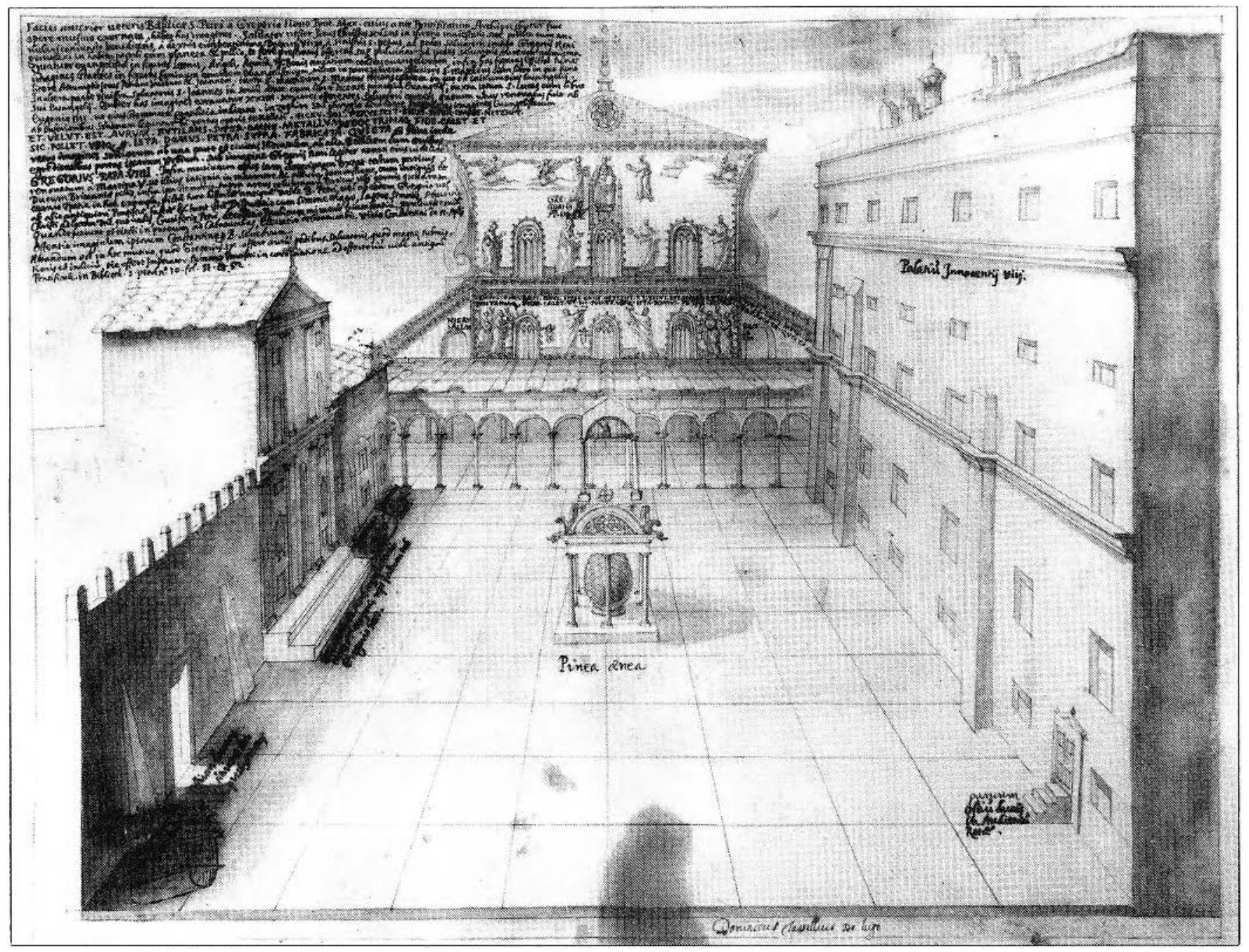

WARMED BY FAITH, JUST SO THIS HOUSE, BUILT UPON A SECURE ROCK, PREVAILS EVERYWHERE. Then in the background of the images of the Elders there is the city of Jerusalem on one side and Bethlehem on the other, with sheep emerging from the gates of those cities. Underneath the image of Gregory is read his name: GREGORIUS PAPA VIIII... ${ }^{35}$

As had happened previously with Innocent's reworking of the early Christian mosaic in the apse, Gregory decided to retain the preexisting theme of the Twenty-Four Elders of the Apocalypse on the facade, yet modify its content with the introduction of Deesis imagery in the centre of the composition. In this case, the thirteenth-century composition addresses the issue of the authority of the Roman primate and seeks to extend some of the earlier ideas expressed by Innocent III in the apse mosaic. This is nowhere more evident than in the wording of the dedicatory inscription, with its reference to hierarchical structure ("THIS HOUSE...
PREVAILS EVERYWHERE"), which alludes to the position of the basilica of Saint Peter's, and Peter's successor, the Roman primate. The inscription, with its explicit reference to the superiority of San Pietro, has been incerpreced by Maccarrone as a crucial step in the development of the "teologia di San Pietro," which saw the papacy during the course of the thirteenth century seeking to elevate the status of the Vatican in relation to the Lateran and justify the notion of papal primacy through a variety of different avenues. ${ }^{36}$ We know, for instance, that Gregory extended the indulgences conferred on pilgrims to the Petrine basilica, thereby contributing to the popularity of this site during the thirteenth century. ${ }^{37}$

We should note the mention in the inscription of the idea that "DOCTRINE IS WARMED BY FAITH." The evidence of late medieval hagiographical literature, as well as the new "interiority and ardour of the faith" documented in the lives of laypeople, such as the Beguines, gives potent 
Figure 4. Exterior of San Pietro in Vaticano by Domenico Tasselli. Rome, Biblioteca Apostolica Vaticana. Barb. lat. 2733, fol. 133v-134 (Photo: Vatican).

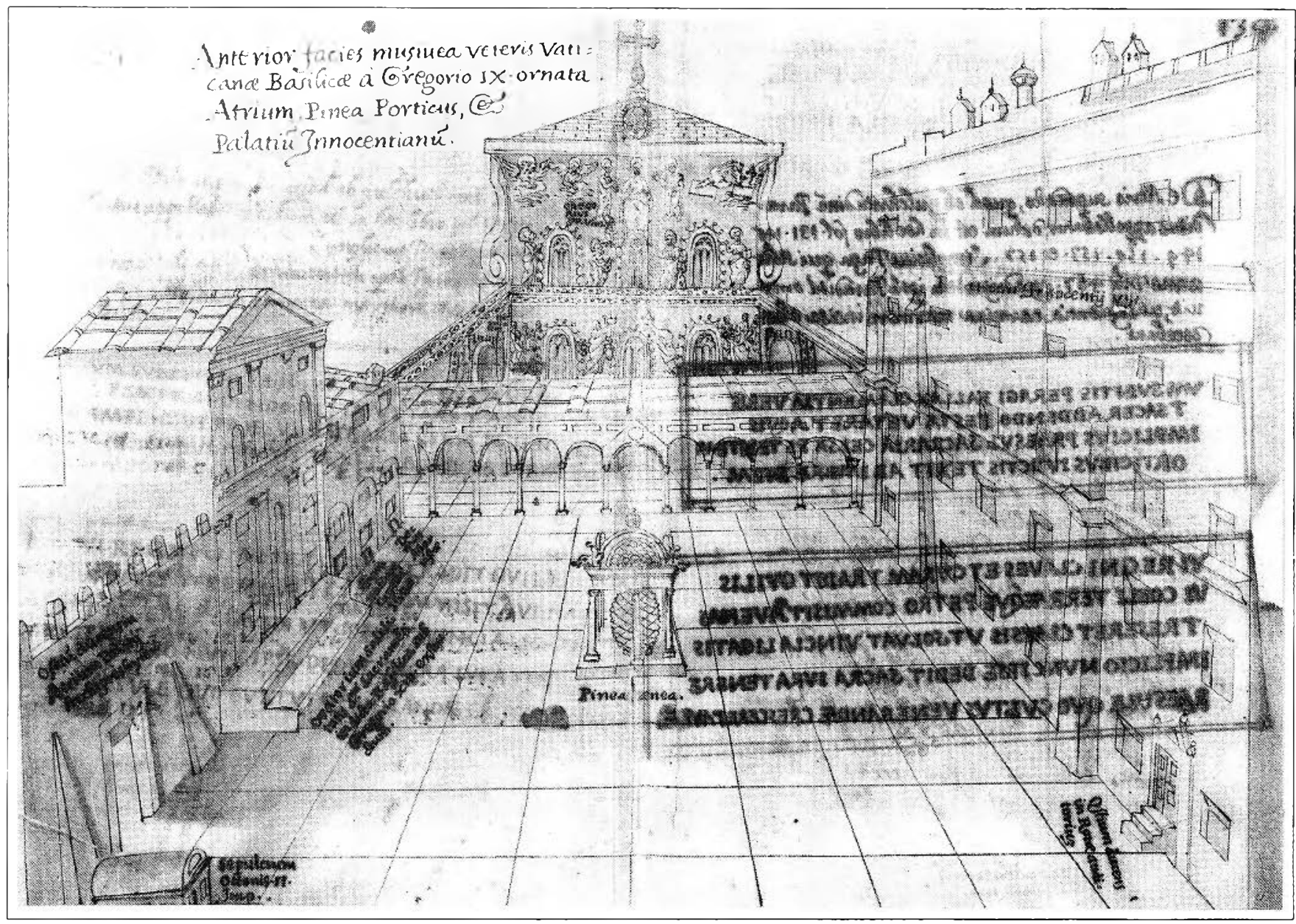

witness to the important shift that took place in contemporary devotional patterns throughout Europe during the thirteenth century. ${ }^{38}$ The reference to the invigorating relationship between doctrine and faith in the mosaic inscription is lent even greater support by the anagogic function of the gold tesserae used in the mosaic. ${ }^{39}$

Gregory's introduction of the "modified" Deesis group (Christ between the Virgin and St Peter) is important, for it may refer to the belief in the intercession of the Virgin and saints at the Day of Judgement, an idea that was not represented previously in the early Christian mosaic. ${ }^{40}$ The composition is best seen in a detail from the image of Italy painted by Cimabue in the late thirteenth century, at San Francesco in Assisi. ${ }^{41}$ It is also significant that Gregory chose to use a "modified" form of the Deesis, with St Peter being substituted for the usual figure of St John the Baptist. As Cutler suggests for Byzantine art, Deesis imagery could often reflect a variant on the usual triadic composition of Saviour, Mother of God and St John; he reminds us furthermore that the meaning of the image cannot be too narrowly defined. ${ }^{42}$ We may never be able to prove whether
Gregory IX intended the Deesis group to represent an emblem of intercession, or an allusion to a special section of the celestial hierarchy at the Day of Judgement. ${ }^{43}$ Cutler admonishes us to reject such either/or systems of thought; in the context of the Petrine facade mosaic, both readings of the Deesis image, related within the larger composition of the Twenty-Four Elders of the Apocalypse, would be acceptable.

There can be little doubt about the great popularity of the Deesis image in late medieval Italy; the traditional Deesis group had, for instance, also formed part of the mid-thirteenth-century Last Judgement fresco displayed in the Silvester chapel at the Quattro Coronati, Rome. ${ }^{44} \mathrm{An}$ important aspect of the medieval Reformation was the awakening study of the Gospel and the early Church Fathers by the whole social body of the Church, which led to a new sense of self-awareness and the importance of conscience, of internal contrition, as people contemplated Christ's example and his condemnation of the sin in the heart. ${ }^{45}$ The social meaning of the Deesis image is therefore related to a general fascination with penance and the role of local saints, 
Figure 5. Portrait of Pope Gregory IX by Alfonso Ciacconio. Rome, Biblioteca Apostolica Vaticana, Vat. lat. 5407, fol. 43 (25) (Photo: Vatican).

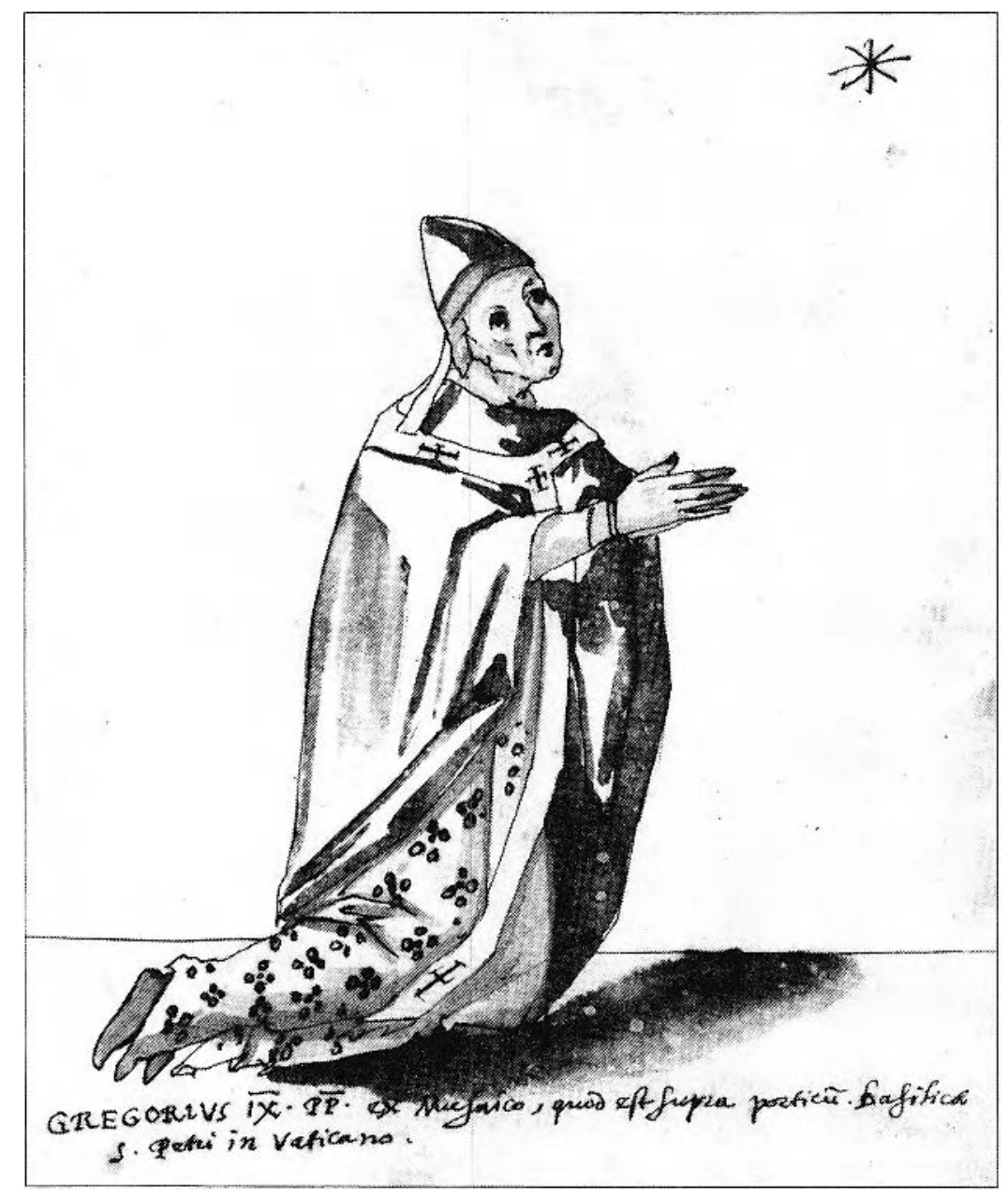

basilica, and his relics are housed here, alluding to the special power and presence of his body in this location. ${ }^{50}$ Gregory thus sought to reiterate the vision of the end of the world that had previously graced the Petrine facade, giving greater emphasis to the special role of the intercessory powers of the patronus of the basilica, as well as asserting the primacy of the head of the Roman church, heir to the apostolic tradition.

Grimaldi's description also suggests that the facade mosaic marks an important stage in the development of papal self-fashioning, for the early Christian original apparently did not feature a representation of the Roman pontiff. The antiquarian scholar Alfonso Ciacconio drew the portrait of Gregory before its destruction, seen in the drawing of 1590 with his hands placed together and raised up to the heavens (fig. 5). Not only is it indicative of a key change in devotional attitudes on the part of the papacy, but it seems clear that this gesture of prayer "signified an offering of oneself in concentrated surrender of body and soul to God." 51 In fact, this particular gesture of prayer was to become common in devotional practices across Italy, through the influence of the Franciscan Order. ${ }^{52}$ Its appearance here in the mosaic decoration denotes an attitude of humility that is entirely consistent with many of

whose powers of intercession assured religious communities of a specific identity and access to a special form of protection. ${ }^{46}$ For instance, the theme of the Deesis recurs in two other facade mosaic projects commissioned in Rome during the latter part of the thirteenth century, now known only through antiquarian drawings and descriptions; those of Santa Maria Maggiore and San Paolo fuori le Mura were apparently modelled in part on the Vatican facade mosaic, although they displayed the more traditional format of the Deesis. ${ }^{47}$ As happened so often, the decoration of Saint Peter's became the model to be followed in terms of the iconography of its facade programme. ${ }^{48}$ In both locations, at Santa Maria Maggiore and San Paolo, the presence and power of a panoply of patron saints were attested to in the monumental facade mosaics. To return again to the inclusion of St Peter in the Deesis group at the Vatican: this detail of the image was probably intended to underscore the saint's special role as gatekeeper of heaven, a theme of great importance on the Day of Judgement. ${ }^{49}$ Another obvious point to be made here is that Peter is the titular saint of the the actions of Pope Gregory IX. Although he is usually portrayed as a cantankerous, ambitious man who spent much of his pontificate fighting with Frederick II,${ }^{53}$ this assessment has been recently challenged by Morris, who asserts that he was also deeply spiritual and involved on many levels with the leaders of the reform movement. ${ }^{54}$ Indeed, there can be little doubt that he was concerned to integrate the dramatic changes occurring in religious life during this period within the mantle of the Mother Church of Rome. ${ }^{55}$ We know, for example, that he saw the new religious orders, such as the Florensians, Franciscans, Dominicans, as forming the main pillars of support for the mother church of Rome. ${ }^{56}$

In contrast to the image of Innocent III in the apse mosaic, this detail of the mosaic projects a conscious image of a humble and pious individual who abases himself in preparation for the Day of Judgement. ${ }^{57}$ In fact, there appear to be two main strategies of self-representation in papal portraits that develop during the late Middle Ages. The first, which would include the images of Innocent III in 
the Vatican apse mosaic and several of the portraits of Boniface VIII (1294-1303), promotes papal identification with the Roman Church and seems to display a strongly "official" character. ${ }^{58}$ The second, which includes the images of Gregory IX and his predecessor Honorius III (12161227), although also promoting identification with the Church, indicates a less authoritarian, more self-effacing and "private" dimension of spiritual devotion. ${ }^{59}$ In a mosaic composition dating to ca. 1216, Honorius III, for example, is similarly shown under the protection of St Lawrence, who intercedes on his behalf, with the Virgin, Christ and St Stephen, in another instance of the "modified Deesis" on the portico frieze of San Lorenzo fuori le Mura, Rome. ${ }^{60}$

Two pieces of evidence indicate that Gregory IX had a clear sense of "impression management," certainly a valuable asset in such troubled times, when the Roman church was being targeted for its lavish displays of wealth and privilege. For example, when Jacques de Vitry was bishop of Acre, he sent Gregory, then Hugolino, Cardinal-Bishop of Ostia, a heavy silver cup filled with nutmeg. According to a papal biographer, Hugolino, a "consistent spurner of material wealth," returned the cup but kept the piece of nutmeg with much pleasure. ${ }^{61}$

Gregory was also a close friend and protector of $\mathrm{St}$ Francis. ${ }^{62}$ In illustration of his great humility, the following story is told: during his cardinalate, he so approved of the life of the Friars Minor that he adapted himself completely to their ways during a visit to them. A contemporary remarked of his attitude that "he was a brother amongst brethren, the lowest among the lowly." ${ }^{3}$ We are reminded of his promotion of the canonization process of St Francis and his encouragement of the writing of the saint's life, which he approved on 25 February $1229 .{ }^{64} \mathrm{He}$ was also instrumental in the canonization process of Dominic, as well as helping the Franciscans and Clares in their search for appropriate rules for their orders during his pontificate. ${ }^{65}$ His presentation of self on the Vatican facade as pious and humble no doubt reflects a general accommodation to the principles of the vita apostolica, and his sense of how the Roman pontiff should steer his ship through the dangerous shoals created by the search for a devout and austere reformed Church.

Of course, this gesture of prayer must be interpreted not only as an indication of contemporary devotional attitudes but also in terms of Gregory's interest in the plenitudo potestatis. As Ladner states: "at a time when feudal overlordship was an important part of the popes' position in the world, of their plenitude of power, they may have wished to see themselves as vassals as it were in the spiritual order: kneeling with joined hands before Christ, though crowned with the papal tiara that sets them over all men." 66

Oddly enough, Ladner was unwilling to accept another detail of Grimaldi's description, which might have lent greater support to his argument. In Grimaldi's notes accompanying the Tasselli sketches, the Vatican archivist stated that Gregory was represented as genuflexus and fere prostratus, in the act of offering Christ a golden coin on a cushion. ${ }^{67}$ The last part of the entry reads (see Addendum):

...It is to be noted in this mosaic that Gregory IX offers gold at the feet of the Saviour, which is a sign of great submission. Thus does the emperor make an offering to the highest pope at the offertory, during the coronation; see the ancient Pontificale in the library of San Pietro no.10, fols. 51 and 52, in these words: depositing his crown and cloak, the Emperor approaches the highest Pope and offers as much gold as he shall wish at his feet. ${ }^{68}$

In spite of a concrete body of evidence that this practice of offering gold was well established by the twelfth century in both papal and imperial ceremonies, Ladner did not feel able to accept Grimaldi's testimony. He felt that it was more likely that Grimaldi had mis-read the round ornament on the cushion under Christ's feet, which can barely be discerned in one of the sketches. Consequently, he claimed that if this detail were to be accepted, it would be a "unique transfer to papal iconography of a motif well known from ancient and medieval political and religious rites." ${ }^{69}$ In the light of what we now know about Gregory's concern for the projection of a certain kind of image, it seems that we might accept Grimaldi's interpretation of the papal gesture. Gregory had placed his offering at the feet of his Saviour as part of a gesture of offering himself up to God, as part of an image stressing his devotion and humility before God, to serve as a model for each and every individual in Christendom. Of course, we are also reminded of the special position of the Roman pontiff in the earthly hierarchy, crowned as he was with the papal tiara that set him apart from other men.

It is worth stressing that another, different motive may have inspired the commissioning of the facade mosaic, for it was probably created in response to a more private moment of devotion as well. Since the beginning of the history of the Christian church, individuals had never ceased to hope for the acquisition of eternal life through the purchase of Paradise: the result was the social practice of commissioning works of art and architecture to convey such heaven-bound aspirations. This practice is well documented in the scholarly literature. ${ }^{70}$ The idea of intercession for one's 
soul in relation to Christ and the Virgin is expressed most clearly in the intercessory mosaic panel of George of Antioch in the Martorana, Palermo, where the idea of the Virgin praying to Christ for the absolution of the donor's sins is stated explicitly in the inscription on her scroll: "O child, shield from all adversity George...and also all his family. Grant (him) absolution from (his) sins..."71 Gregory was obviously no exception to this social practice. In a similar manner, and in a daring moment of innovation in Western art, Gregory chose to direct his hope of salvation to two powerful advocates before Christ: the Virgin and the heavenly gatekeeper, St Peter, both of whom would be well placed to represent his case and presumably be prepared to have a special regard for Peter's representative on earth.

\section{Addendum}

Text by G. Grimaldi, Album A 64 Ter, fol.10; transcribed by Grisar, "Il Prospetto," 489-90.

\section{Document 1:}

Facies anterior veteris basilicae Sancti Petri a Gregorio Nono pontifice maximo cuius ante pontificatum archipresbyter fuit opere musivo exornata, habet has imagines: Salvator noster Jesus Christus sedens in throno maiestatis suae, pollice cum anulari coniuncto benedicens, a dextera eius beatissima Deipara virgo, a sinistris S. Petrus. Ad pedes Salvatoris imago Gregori Noni genuflexi in habitu papali cum planeta et pallio, et fere prostratus offerens super pulvinar ad pedes Salvatoris aurem numisma. Quattuor evangelistae in figuras [sic] leonis, angeli, aquilae et bovis tenetium codices evangelorum. Infra has figuras effictae sunt imagines stantes in figuras hominum eorundem evangelistarum scilicet in parte dextera Salvatoris, Sanctus Mattheus cum libro in quo sunt litterae ASSUMPSIT JESUS PETRUM JACOBUM ET JOANNEM. Iuxta sanctum Mattheum sanctus Marcus tenens codicem in quo est initium eius evangelii. In altera aetate cum libro dicente principium evangelii. Iuxta ipsum sanctus Lucas cum libro sui evangelii. Subter has imagines cernuntur XXIIII seniores offerentes Salvatori coronas quorum unius renovatus fuit ab Eugenio Quarto, et eius stemmata gentilicia indicant. In zophoro seu ab inferioribus seniorum legunter hi versis operis tessellati: CEU SOL FERVESCIT SIDUS SUPER OMNE MITESCIT/ET VELUT EST AURUM RUTILANS SUPER OMNE METALLUM/DOCTRINAQUE FIDE CALET ET SIC POLLET UBIQUE/ ISTA DOMUS PETRA SUPER FABRICATA QUIETA. Hinc inde retro imagines seniorum ab una parte est civitas Hierusalem ab alia Bethleem cum ovibus egredientibus portas ipsarum urbium. Sub imagine Gregori Noni legitur nomen eius videlicet: GREGORIUS PAPA VIII... Notandum est in hoc musivo quod Gregorius Nonus offert aurum pedibus Salvatoris quod magnae summissionis est iudicium; sic offert imperator summo pontifici in coronatione ad offertorium, vide antiquum pontificale in biblioteca Sancti Petri, n.10, fol. 51 et 52 his verbis: Imperator corona et manto depositis accedat ad summum pontificem offert ad pedes eius aurum, quantum sibi placeruit.

Notes

Dedicated to Brenda Bolton, who introduced me to the medieval Reformation. I would like to thank Ariane Isler-de Jongh, Gillian Mackie and John Osborne for their generous support and helpful comments.

1 See in particular, E. W. McDonnell, "The Vita Apostolica: Diversity or Dissent?" Church History, XXIV (1955), 15-31; H. Grundmann, Religiöse Bewegungen im Mittelalter, 2nd edn. (Darmstadt, 1970), esp. 13-69; B. Bolton, The Medieval Reformation (London, 1983).

2 C. Morris, The Papal Monarchy: the Western Church from 1050 to 1250 (Oxford, 1989), 417-51, 483-86, 563-66.

3 Morris, Papal Monarchy, 452-77.

4 For the vita apostolica, as well as Innocent's response to it, see Bolton, Reformation, 19-21, 100. For general attitudes to wealth in the period, see L. Little, Religious Poverty and the Profit Economy in Medieval Europe (Ithaca, 1978); A. Vauchez, The Laity in the Middle Ages, ed. D. Bornstein, trans. M. Schneider (Notre Dame and London, 1993), 3-27.

5 See The Book of Pontiffs (Liber Pontificalis), trans. R. Davis (Liverpool, 1989); B. Ward-Perkins, From Classical Antiquity to the Middle Ages (Oxford, 1984), 49-85; B. Kempers, Painting, Power and Patronage (London, 1987), 22-26.

6 R. Krautheimer, Rome: Profile of a City, 312-1308 (Princeton, 1980), 204-05.

7 H. Schroder, Die kunstfordernde Tätigkeit der Papste im 13. Jahrhundert (Leipzig, 1931).

8 R. Krautheimer, St. Peter's and Medieval Rome (Rome, 1985), 33; and B. Bolton, "A Show with a Meaning: Innocent's Approach to the Fourth Lateran Council, 1215," Medieval History, I (1991), 53-67.

9 Bolton, "A Show with a Meaning", 53-67, and B. Bolton, "Advertise the Message: Images in Rome at the Turn of the Twelfth Century," Studies in Church History: The Church and the Arts, XXVIII (Oxford, 1992), 117-30.

10 As discussed in M. Rubin, Corpus Christi. The Eucharist in Late Medieval Culture (Cambridge, 1991), 323.

11 The earlier literature is discussed in C. Harding, "Facade Mosaics of the Dugento and Trecento in Tuscany, Umbria and Lazio," Ph.D. Diss., University of London, 1984, 149-60. 
$12 \mathrm{~J}$. Alexander, "Iconography and Ideology: Uncovering Social Meanings in Western Medieval Christian Art," Studies in Iconography, XV (1993), 1-44; K. Moxey, The Practice of Theory (New York, 1994), 29-40.

13 Krautheimer, Rome, 205. See also the recent contribution by A. lacobini, "Il mosaico absidale di San Pietro in Vaticano," Fragmenta Picta: affreschi e mosaici staccati del medioevo romano (Rome, 1989), 119-29, with full bibliography.

14 G. Grimaldi, Rome, Archivio della Basilica di S. Pietro, Album, A 64 Ter, fol. 50. See also C. Ihm, Die Programme der christlichen Apsismalerei vom vierten Jahrhundert bis zur Mitte des achten Jahrhunderts (Wiesbaden, 1960), 11-41.

15 See C. Davis-Weyer, "Das Traditio-Legis Bild und seine Nachfolge," Münchner Jahrbuch, XII (1961), 7-45.

16 G.B. Ladner, "The Gestures of Prayer in Papal Iconography of the Thirteenth and Early Fourteenth Centuries," Didascalie, Studies in Honor of Anselm M. Albareda, ed. P. Sesto (New York, 1961), 247-75, esp. 248-49.

17 Krautheimer, Rome, 206, notes that the inscription challenges the customary importance of the Lateran by adopting its title: "Mother of all Churches." Bolton, "Advertise the Message," 117 30, stresses that Innocent sought to raise the status of Saint Peter's in relation to the Lateran, so that he might heal the damaging rivalry between the two institutions that had developed over the centuries.

18 B. Bolton, "In Spirit and in Stone: The Building Projects of Innocent III," paper presented in London, U.K., for members of the British School at Rome, on 14 February 1983.

19 J. Osborne, "A Carolingian Agnus Dei Relief from Mola di Monte Gelato, near Rome," Gesta, XXXIII (1994), 73-78, esp. 75. I would like to thank J. Osborne for bringing this reference to my attention.

20 Rubin, Corpus Christi, 53.

21 Morris, Papal Monarchy, 437.

22 Bolton, "Advertise the Message," 129.

23 Schroder, Die kunstfordernde Tätigkeit, 36, states that Gregory also gave a costly golden cross to Saint Peter's.

24 Ad Innocenti III Vitam Addimentum, ed. A. Card. Mai, in Spicilegium Romanum, VI (Rome, 1841), 302: "Absidam eiusdem basilicae fecit decorari musivi et in fronte ipsius basilicae fecit restaurari musivum quod ex magna parte consumptum..."

25 See Vita Gregori IX, Liber Censuum de l'Église Romaine, eds P. Fabre and L. Duchesne, 2 vols (Paris, 1899, 1910), II, 23: "Tunc in basilica vero Apostolorum principis in maioris porte vestibulo parietem altitudine pregrandi erectum vestivit lapide deaurato, nobilium imaginum decore discinctum."

26 The fragmencary remains of the facade mosaic are examined by F. Gandolfo, "Il ritratto di Gregorio IX dal mosaico di facciata di San Pietro in Vaticano," 131-34; A. Ghidoli, "La testa di S. Luca dal mosaico di facciata di San Pietro in Vacicano," 135 38; M. Andaloro, "'A dexceris eius beatissima Deipara Virgo': dal mosaico della facciata vaticana," 139, in Fragmenta Picta.
27 R. Krautheimer, Corpus Basilicarum Christianarum Romae, 5 vols (1977), V, 222; 256-57. It is not clear what structural repairs were carried out based on the evidence of the Liber Pontificalis, trans. Davis, xxi-xxii.

28 Unfortunately, we know little or nothing about Marinianus, except that he served as consul in 423 and was still alive in 448 when his son Rufius Praetextus was made consul: G. B. de Rossi, Inscriptiones Christianae Urbis Romae septimo saeculo antiquiores, 2 vols (Rome, 1857-88), II (1888), 9.

29 Osborne, "A Carolingian Agnus Dei," 75.

30 The theme of the Elders of the Apocalypse at the Vatican is examined by F. van der Meer, Maiestas Domini. Theophanies de l'Apocalypse (Vatican City, 1938), esp. 93, and J. Engemann, "Images parousiaques dans l'art paleochrétien," L'Apocalypse de Jean, Actes du Colloque de la Fondation Hardt (Geneva, 1979), 73-108.

31 P. Claussen, Chartres - Studien zu Vorgeschichte, Funktion und Skulptur der Vorhallen (Wiesbaden, 1975), 3-26.

32 The study by $\mathrm{H}$. Grisar, "Il prospetto dell'antica Basilica Vaticana," in Analecta Romana (Rome, 1899), I, 463-506, remains of fundamental importance; more recently, see the work of M. Andaloro, "Ancora una volta sull'Ytalia di Cimabue," Arte Medievale, II (1984), 143-77, esp. 155-57.

33 R. Malmstrom, "S. Maria in Aracoeli in Rome," Ph.D Diss., New York University, 1973, 246-53.

34 Krautheimer, Corpus, V, 256-57.

35 I am grateful to William McQuaig for providing me with this translation.

36 M. Maccarrone, "L'indulgenza del Giubileo del 1300 e la basilica di S. Pietro," in Roma anno 1300, ed. A.M. Romanini (Rome, 1983), 731-52, esp. 737-78. See Innocent's contribution to this development as discussed above, n. 17.

37 Maccarrone, "L'indulgenza," 738, n. 40.

38 A. Vauchez, "Saints admirables et saints imitables: les fonctions de l'hagiographie ont-elles changé aux derniers siècles du Moyen Age?," in Les fonctions des saints dans le monde occidental (IIIXIIIe siecles) (Rome, 1991), 161-72, esp. 171

39 For a parallel case where the anagogic function of materials is employed to similar effect, see Abbor Suger and Saint Denis, as related by Abbot Suger on the Abbey-Church of Saint-Denis, ed. and trans. E. Panofsky; 2nd edn G. Panofsky-Soergel (Princeton, 1979), 47, 162-63; see also Harding, "Facade Mosaics," 28-31.

40 The literature on the Deesis is extensive, but see M. Andaloro, "Note sui temi iconografici della Deesis e della Haghiosoritissa," Rivista dell'Istituto Nazionale di Archeologia e di Storia del'Arte, XXVII (1970), 85-153, and A. Cucler, "Under the Sign of the Deesis: On the Question of Representativeness in Medicval Art and Literature," Dumbarton Oaks Papers, XVII (1987), 145-54, for a discussion of the key issues in its interpretation.

41 As reproduced in E. Battisti, Cimabue (University Park and London, 1967), pl. 9

42 Curler, "Under the Sign," 153. 
43 Cutler, "Under the Sign," 146.

44 For the Last Judgement mural in the Silvester chapel at SS. Quattro Coronati, see F. Hermanin, L'Arte in Roma dal Sec. VIII al XIV (Bologna, 1945), pl. CXLV.

45 Bolton, Reformation, 17.

46 See the important contribution by Vauchez, "Patronage of Saints and Civic Religion in the Italy of the Communes," Laity in the Middle Ages, 153-68.

47 Harding, "Facade Mosaics," esp. 171-87; J. Gardner, "Pope Nicholas IV and the Decoration of Santa Maria Maggiore," Zeitschrift für Kunstgeschichte, XXXIV (1971), 1-50; and P. Hetherington, Pietro Cavallini: A Study in the Art of Late Medieval Rome (London, 1980), 110-13.

48 H. Kessler, "'Caput et speculum omnium ecclesiarum': Old St. Peter's and Church Decoration in Medieval Latium," Italian Church Decoration of the Middle Ages and Early Renaissance, ed. W. Tronzo (Bologna, 1989), 119-46.

49 For a useful background to the concept of Peter as the gatekeeper of heaven, see T. Zwölfer, Sankt Peter, Apostelfürst und Himmelspfortner: Seine Verehrung bei den Angelsachsen und Franken (Stuttgart, 1929).

50 P. Brown, The Cult of Saints (Chicago, 1981), 86-127, discusses the importance of saintly praesentia within specific cultic locations.

51 Ladner, "Gestures of Prayer," 252, 264.

52 Ladner, "Gestures of Prayer," 247-75.

53 Negative assessments of Gregory are provided by T.C. van Cleve, The Emperor Frederick II of Hohenstaufen (Oxford, 1972), esp. 427; D. Abulafia, Frederick II: A Medieval Emperor (London, 1988).

54 Morris, Papal Monarchy, 564-66.

55 Morris, Papal Monarchy, 467.

56 S. Wessley, Joachim of Fiore and Monastic Reform (New York, 1990), 89

57 For Gregory's spiritualicy and deep faith, see R. Brooke, Early Franciscan Government (Cambridge, 1959), 70.

58 J. Gardner, "Boniface VIII as a Patron of Sculpcure," in Roma anno 1300, ed. Romanini, 513-22.

59 A portrait of Honorius III may be seen in the apse mosaic of San Paolo fuori le Mura, Rome, as discussed and illustrated in
Ladner, "Gestures of Prayer," 249-50, fig. 3.

60 As discussed and illustrated in A. Muñoz, La Basilica di S. Lorenzo fuori le Mura (Rome, 1944), 78, pl. II.

61 B. Bolton, "Vitae Matrum: A further Aspect of the Frauenfrage," in Studies in Church History, ed. Baker, 253-73, esp. 271.

62 He was involved with the laying of the foundation stone of the basilica at San Francesco at Assisi, as discussed in Schroder, Die kunstfördernde Tätigkeit, 36-37.

63 C. Esser, The Origins of the Franciscan Order (Chicago, 1970), 179; see also Brooke, Early Franciscan Government, 56-122.

64 J.H. Smith, Francis of Assisi (New York, 1972), 138, 146, 171, 197-98; and A. Mockler, Francis of Assisi (Oxford, 1976), 1617.

65 R. Brooke and C. Brooke, "St. Clare," Studies in Church History, Subsidia, ed. D. Baker (Oxford, 1978), I, 275-87.

66 Ladner, "Gestures of Prayer," 264. For Gregory's use of the term "Vicarius Christi" and its relation to the plenitudo potestatis, see M. Maccarrone, Vicarius Christi: Storia del titulo papale (Rome, 1952); and G. B. Ladner, "The Concepts of 'Ecclesia' and 'Christianitas' and their Relation to the Idea of Papal 'Plenitudo Potestatis', from Gregory VII to Boniface VIII," in Sacerdozio e regno da Gregorio VII a Bonifacio VIII (Misc. hist. pont. 18), ed. Ecclesiastical History Faculty, Univ. Pont. Gregoriana (Rome, 1954), 49-77.

67 In the sketch by Tasselli, Gregory is shown as genuflexus, while Grimaldi's use of the term fere prostratus would suggest a pose similar to that assumed by Pope Honorius III in the San Paolo apse mosaic. It is impossible to state definitively whose version is correct, given the paucity of evidence concerning the commission.

68 See Addendum for this latter part of the entry after the ellipsis.

69 Ladner, "Gestures of Prayer," 251.

70 See, for example, R. Deshman, "Servants of the Morher of God in Byzantine and Medieval Arr," Word and Image, V (1989), 3370, who examines images representing various donor figures in attitudes of humility in Early Medieval and Byzantine art. See also J. Rosenthal, The Purchase of Paradise (London and Toronco, 1972), for late medieval practices in England.

71 E. Kitzinger, The Mosaics of St. Mary's of the Admiral in Palermo (Washington, 1990), 197-211, 313-18, esp. 317, pl. XXII. 